\title{
D]d
}

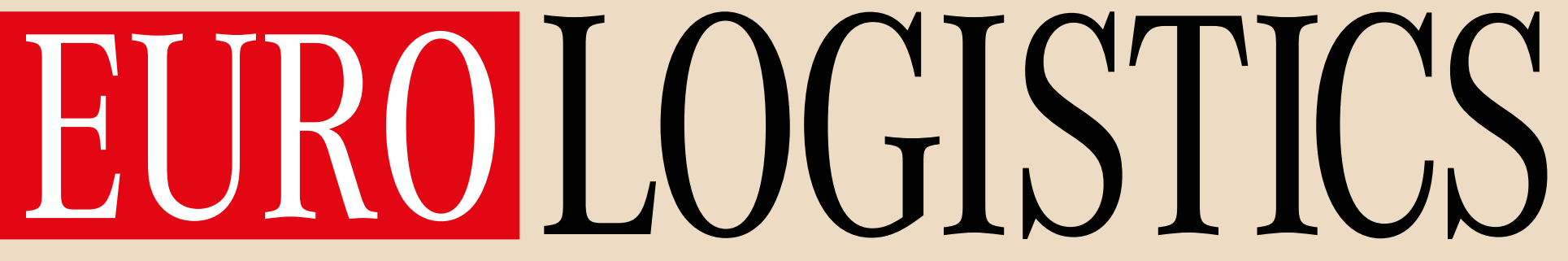

SONDAŻ

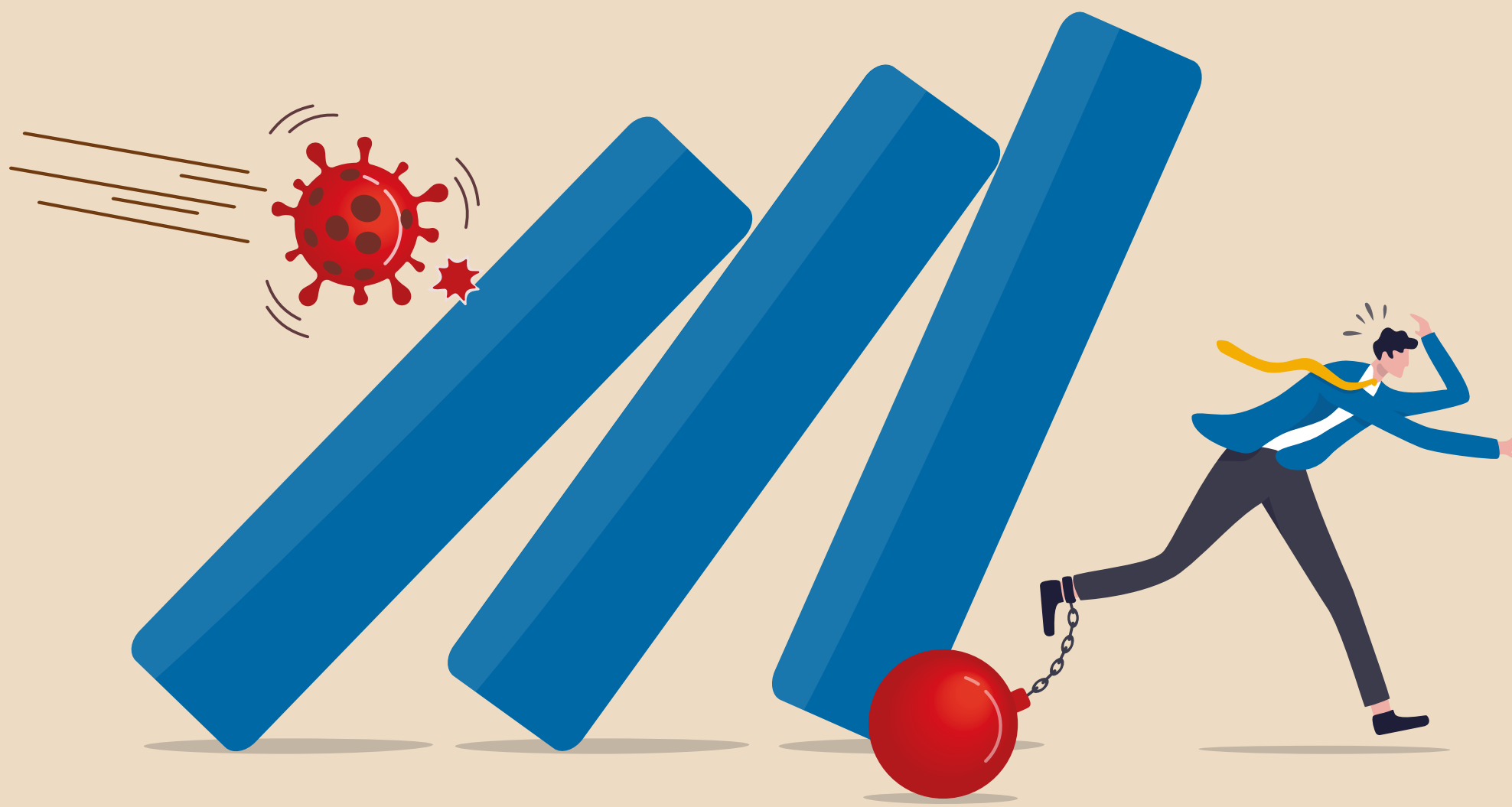

RYNEK LOGISTYCZNY

W DOBIE PANDEMII

COVID-19 
W pierwszych tygodniach od wybuchu pandemii Covid-19 przedsiębiorstwa z branży logistycznej i transportowej stanęły przed poważnymi wyzwaniami, aby zapewnić ciągłość operacji i łańcuchów dostaw. Jakie podjęły działania, z jakimi zagrożeniami musiały się mierzyć? Firma DGC na zlecenie wydawnictwa Eurologistics przygotowała sondaż wśród firm logistycznych i transportowych, którego celem jest udokumentowanie na gorąco stanu rynku usług logistycznych w pierwszych tygodniach po wybuchu pandemii.

$\mathrm{S}^{\mathrm{tan}}$ raliśmy się uchwycić najważniejsze zmiany w stosunku do stanu normalnego za pomocą takiego narzędzia pomiarowego, które zastosowane ponownie pokaże skalę i tendencję zachodzących zmian. Poniżej prezentujemy wyniki pierwszego sondażu. W badaniu skupiliśmy się na trzech zagadnieniach: działaniach podjętych przez firmy logistyczne dla zapewnienia ciągłości operacji w warunkach pandemii, zagrożeniach dla działalności firm logistycznych oraz aktywności poszczególnych branż w dziedzinie zakupu usług logistycznych.

\section{Zapewnienie ciągłości operacji}

Przedsiębiorstwa logistyczne podobnie jak wszystkie inne instytucje poddały się nadzwyczajnym środkom ograniczającym kontakt bezpośredni. Wprowadza się ograniczenia kontaktu własnych pracowników z pracownikami innych firm, kurierami, listonoszami. Wydzielone zostają odrębne strefy dla pracowników własnych i obcych, przede wszystkim w magazynach. Likwiduje się bądź ogranicza rozliczenia na zasadzie dokumentacji papierowej. Prawdziwym panaceum na lęk wywołany zagrożeniem epidemicznym miała być praca zdalna, podział pracowników na część dyżurującą w miejscu pracy i całą resztę wykonujących pracę w domu. Przez wiele dni temat nie schodził z czołówek gazet i głównych stron portali internetowych, stając się typowym tematem zastępczym dla kwestii poważniejszych - groźby wywołanej zarazą. Dyskutowano namiętnie, na ile praca zdalna jest do zastosowania także w „normalnych czasach”. Efektywność tego rozwiązania okazała się jednak w praktyce marna, samo nawiązanie kontaktu z pracującymi zdalnie - nadzwyczaj trudne. W istocie rzeczy chodzito pracodawcom o próbę ukrycia braku pracy do wykonania, blisko połowa przyznaje przecież, że była zmuszona urlopować część pracowników. Aż 2/5 wycofała z ruchu część floty samochodowej bądź ograniczyła korzystanie z usług obcych przewoźników (ewentualnie zatrudnionych na zewnątrz pracowników magazynów). Zwolnienia części pracowników to ciągle bardziej groźba niż rzeczywistość - uciekła się do tego kroku mniej niż co piąta firma logistyczna. Dużo częściej decydowano się na jakąś formę obniżenia stawek płacowych (29\% wskazań). Pocieszające jest, że prawie równie często (28\%) stosuje się obecnie dodatkowe premiowanie za gotowość do pracy.
O ile na ogół najczęściej wysyła się ludzi na przymusowe urlopy, w dalszej kolejności proponuje się obniżenie stawek płacowych, a dopiero w ostateczności zwalnia część załogi, to w małych firmach pierwszy etap (urlopowanie) zostaje odwołany, od razu następuje „etap prawdy” (obniżanie stawek płacowych). W ciągu miesiąca pandemii przeprowadzono go w blisko połowie małych firm, dwukrotnie częściej niż w pozostałych. Następny etap - zwolnienia, dotkną co trzeciej małej firmy i tylko 14\% pozostałych.

Warte zastanowienia jest, że ogólna sytuacja firm transportowych jest obecnie dużo gorsza niż firm spedycyjnych, kurierskich, zajmujących się obsługą handlu elektronicznego czy logistyką kontraktową. Dużo większa ich część wysyła pracowników na urlopy, obniża im płace, a zbędnych zwalnia.

\section{Zagrożenia dla działalności}

Na działalność firm logistycznych negatywnie nakładają się obecnie (początek kwietnia) zarówno chronologicznie wcześniejszy spadek zapotrzebowania na usługi, jak i trudności finansowe, które z czasem się pogłębiają. Charakterystyczne, że 4/5 firm odnotowujących spadek zapotrzebowania na usługi zgłasza nadmierne obciążenie zobowiązaniami finansowymi i zatorami płatniczymi, co dobitnie wskazuje na przyczynę kłopotliwej sytuacji blisko połowy badanych firm. Ważną dla tej grupy firm składową załamania się popytu na usługi logistyczne jest zerwanie łańcuchów dostaw międzynarodowych. Zmiany struktury zapotrzebowania na usługi stanowią dodatkowe wyzwanie. Nadspodziewanie zakłócenia w przepływie towarów (ograniczenia ruchu, kontrole sanitarne) oraz ograniczenia w prowadzeniu działalności za granicą w wyniku zamknięcia granic dla większości firm nie stanowią problemu. Zupełnie z orbity zainteresowania zniknęty z oczywistych powodów jeszcze do niedawna kluczowe kwestie niedoboru kierowców oraz wysokości stawek przewozowych (mniejsza liczba zamówień, tanie paliwo, wysoki kurs euro).

Ogólna sytuacja firm transportowych jest obecnie dużo gorsza niż pozostałych, ponieważ znacznie częściej dotyka je spadek zapotrzebowania na usługi. Choć zatory płatnicze nie obciążają tego rodzaju firm dużo bardziej niż innych, to zobowiązania finansowe (zakup bądź leasing środków transportów) już tak. Spadek zapotrzebowania i obciążenie spłatą rat 
kredytów podwójnie silnie wpływa na ten sektor logistyki. Inne sektory logistyki nie notują aż tak dużego spadku popytu ani nie dysponują tak kosztownymi w utrzymaniu zasobami.

Blisko 2/3 (62\%) firm transportowych silnie odczuwa spadek popytu, dokładnie odwrotnie niż firmy wyspecjalizowane w logistyce kontraktowej czy usługach ekspresowych i kurierskich. Jeszcze lepszą sytuację deklarują firmy obsługujące handel elektroniczny. Korzystają nie tylko z nadmiernego gromadzenia zapasów przez klientów, ale także z ich chęci unikania fizycznego kontaktu w sklepach detalicznych (z drugiej strony wydatki na odzież i na sprzęt znacznie spadły). Trochę lepiej niż firmy transportowe radzą sobie także spedycje drogowe (47\% odczuwa silny negatywny wpływ spadku popytu). Wprawdzie prawie wszystkie spedycje lotnicze i morskie odczuły zerwanie łańcuchów dostaw międzynarodowych, to spadek popytu uznają za umiarkowany, mimo zmiany kierunków geograficznych i asortymentu realizowanych dostaw. Im firma jest większa, tym mniej odczuła spadek zapotrzebowania na usługi. Jeśli 30\% spośród firm o przychodach powyżej $100 \mathrm{mln}$ zł boryka się z bardzo poważnymi problemami z tego powodu, to wśród firm o przychodach do $10 \mathrm{mln}$ jest takich aż 63\%. Mniejsze firmy dwukrotnie częściej niż pozostałe dotyka też groźba utraty płynności w wyniku powstania zatorów płatniczych (68\% firm o przychodach do $10 \mathrm{mln}$ i 58\% firm o przychodach od $10 \mathrm{mln}$ do $25 \mathrm{mln}$ ). Większość małych firm (72\% firm o przychodach do $10 \mathrm{mln}$ ) sugeruje, że nie będzie w stanie uregulować zobowiązań podatkowych. Obciążenia wobec państwa przedstawiają się jako groźniejsze niż obciążenia wobec instytucji finansowych (dla 63\% firm o przychodach do 10 mln konieczność spłaty tych zobowiązań może być niemożliwa).

\section{Aktywność branż w zakupie usług logistycznych}

Sytuacja firm logistycznych w dobie pandemii w oczywisty sposób różnicuje się ze względu na stopień uzależnienia od zamówień konkretnych branż. Firmy wyspecjalizowane w dostawach artykułów spożywczych i chemii użytkowej oraz obsłudze handlu elektronicznego mogą korzystać ze wzmożonych zakupów klientów detalicznych, przez co osiągają szczególną przewagę w stosunku do tych firm logistycznych, które obsługują branże (a często są od tych relacji uzależnione), w których sprzedaż towarów w praktyce zamarła, jak np. samochodów i akcesoriów motoryzacyjnych (zdecydowany spadek aktywności zakupowej odnotowuje w tym zakresie aż 72\% firm logistycznych). Te pierwsze w odróżnieniu od tych drugich raczej nie wysyłają pracowników na urlop, lecz starają się dodatkowo premiować ich gotowość do pracy. Nie mają powodów od obniżenia stawek wynagrodzeń a tym bardziej zwolnień zbędnych pracowników. Choć również odczuwają zaburzenia w gospodarce, to płynność finansowa większości z nich nie jest zagrożona.

O ile uzależnienie od obsługi konkretnej branży może być ryzykowne, to posiadanie jako takiej umiejętności zarządzania łańcuchem dostaw, tak jak to się dzieje w logistyce kontraktowej, daje dużą szansę przetrwania krachu w gospodarce. Porównując sytuację firm wyspecjalizowanych w logistyce kontraktowej z sytuacją firm wyspecjalizowanych w transporcie i spedycji drogowej (i po wyeliminowaniu wpływu czynnika wielkości przedsiębiorstw), widzimy, że w prawie wszystkich branżach pozycja tych pierwszych jest lepsza. W branżach dołujących obniżki zamówień są proporcjonalnie mniejsze, w branżach rosnących - większe. O ile w branży elektronicznej firmy transportowe notują umiarkowany spadek liczby zamówień, to sektor logistyki kontraktowej może się pochwalić utrzymaniem wielkości zamówień na poprzednim poziomie.

---

Choć ciągle jeszcze optymistyczny scenariusz rozwoju sytuacji jest możliwy, a wtedy szybki powrót do normalności dawałby fantastyczne perspektywy ożywienia gospodarki, to ani na jotę nie oddaliło się potencjalnie ryzyko niebywałej katastrofy. Pewne jest, że pandemia Covid-19 wprowadziła rynek usług logistycznych na niespotykany dotąd poziom niepewności. Jakkolwiek kryzys przynosi ogólnie złe wieści, to staraliśmy się pokazać, że można i należy szukać wyjścia z najbardziej nawet niekorzystnych okoliczności. Obecnie to platformy cyfrowe oraz firmy logistyczne i firmy świadczące usługi ekspresowe stają się beneficjentami kryzysowej sytuacji. W następnym sondażu (początek maja) chcemy zatem podjąć temat zmian koniecznych w organizacji logistyki w dobie pandemii. Bądźcie zdrowi!

Zespół DGC/Eurologistics

\section{O sondażu:}

Rynek logistyczny w dobie pandemii Covid-19. Nr 1 , Tydzień 14/2020. Liczba wywiadów 80. Grupa docelowa: menedżerowie firm logistycznych. Najliczniej reprezentowane $w$ próbie grupy to firmy specjalizujące się w transporcie drogowym (45\%) [podobną proporcję odnotowujemy w rankingu pięciuset największych firm Top500] oraz duże firmy o przychodach powyżej $100 \mathrm{mln}$ zł (35\%) [identycznie jak w tym rankingu]. 


\section{Działania podjęte przez firmy logistyczne dla zapewnienia ciągłości operacji w warunkach pandemii}

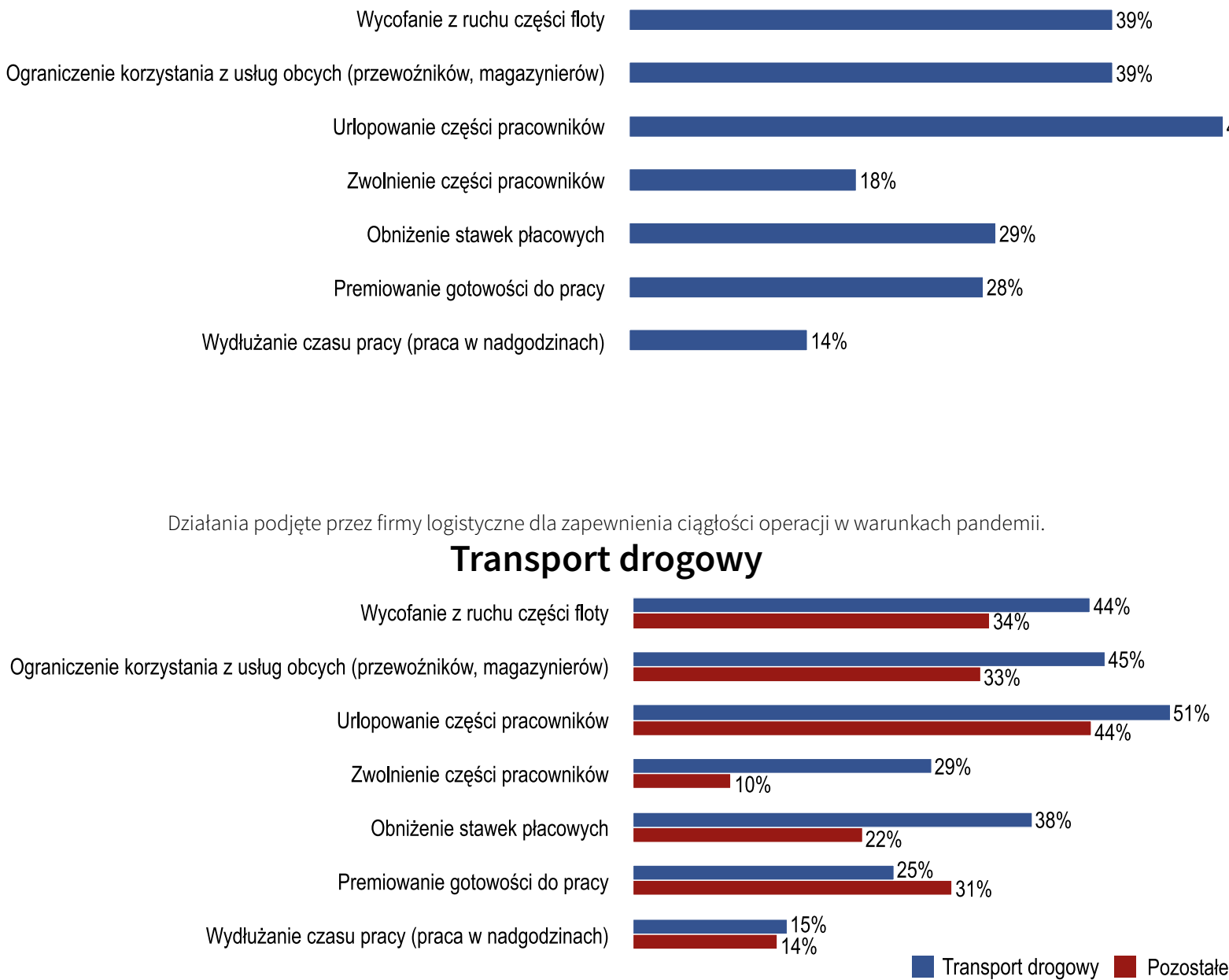

Działania podjęte przez firmy logistyczne dla zapewnienia ciągłości operacji w warunkach pandemii.

\section{Małe firmy (przychody do $10 \mathrm{mln}$ )}

Wycofanie z ruchu części floty

Ograniczenie korzystania z usług obcych (przewoźników, magazynierów)

Urlopowanie części pracowników

Zwolnienie części pracowników

Obniżenie stawek płacowych

Premiowanie gotowości do pracy

Wydłużanie czasu pracy (praca w nadgodzinach)

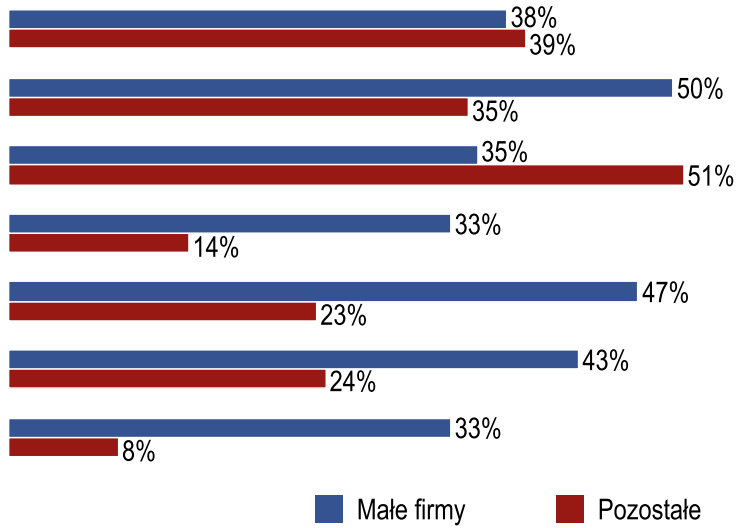




\title{
Silny negatywny wpływ na działalność firm logistycznych
}

\author{
(początek kwietnia 2020)
}

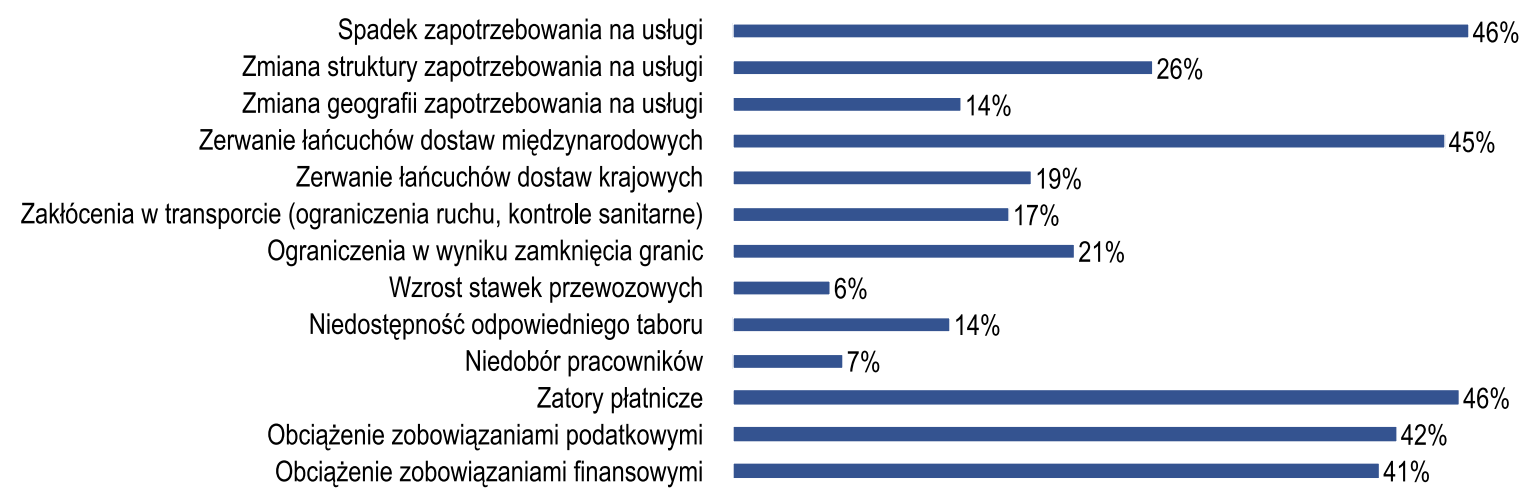

Silny negatywny wpływ na działalność firm logistycznych (początek kwietnia 2020). Specjalizacja rynkowa. Spadek zapotrzebowania na usługi

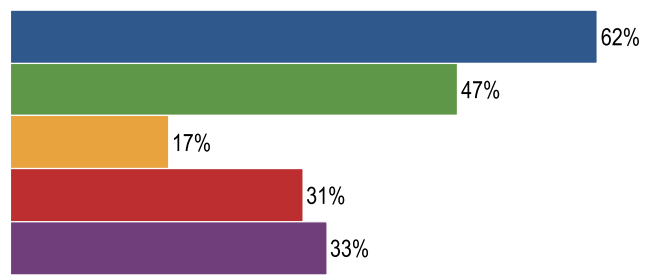

$0 \%$

Transport drogowy Spedycja drogowa Spedycja lotnicza i morska Logistyka kontraktowa

Silny negatywny wpływ na działalność firm logistycznych (początek kwietnia 2020). Specjalizacja rynkowa.

\section{Zatory płatnicze}

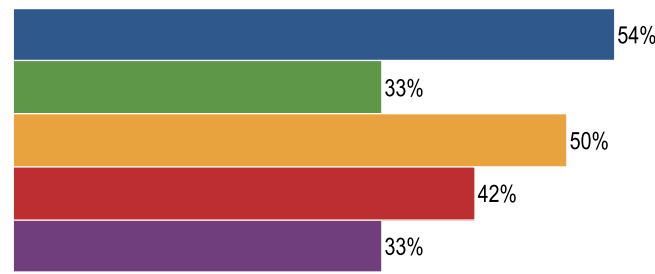

$0 \%$

Transport drogowy

Logistyka kontraktowa

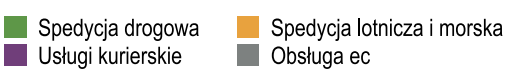

Silny negatywny wpływ na działalność firm logistycznych (początek kwietnia 2020). Specjalizacja rynkowa.

Obciążenie zobowiązaniami finansowymi

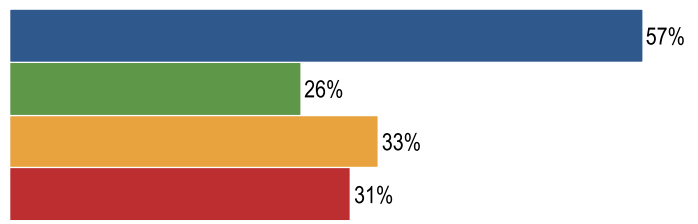

$0 \%$

$0 \%$

Transport drogowy Logistyka kontraktowa
Silny negatywny wpływ na działalność firm logistycznych (początek kwietnia 2020). Specjalizacja rynkowa. Zerwanie łańcuchów dostaw międzynarodowych

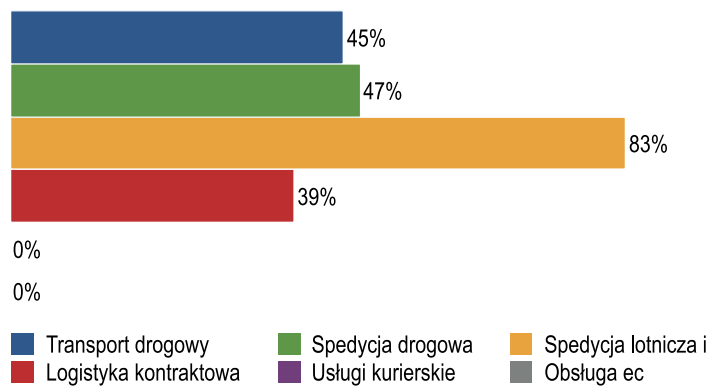

Silny negatywny wpływ na działalność firm logistycznych (początek kwietnia 2020). Specjalizacja rynkowa.

\section{Obciążenie zobowiązaniami podatkowymi}

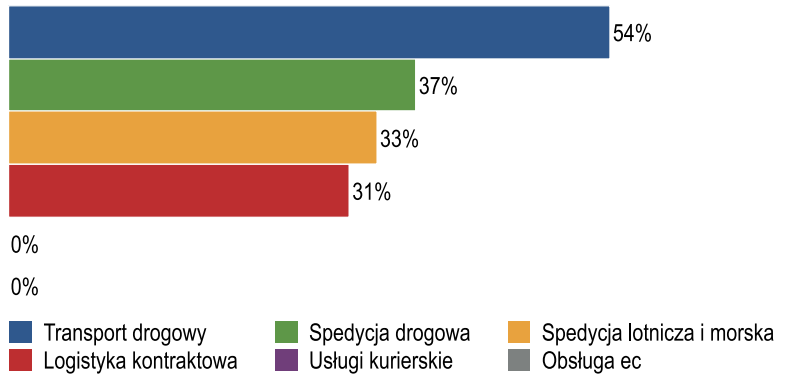

Ogólna sytuacja firm

transportowych jest

obecnie dużo gorsza niż firm

spedycyjnych, kurierskich,

zajmujących się obsługą

handlu elektronicznego czy

logistyką kontraktową. 


\section{Silny negatywny wpływ na działalność firm logistycznych}

(początek kwietnia 2020)

\section{Wielkość przychodów}

Silny negatywny wpływ na działalność firm logistycznych (początek kwietnia 2020). Wielkość przychodów Spadek zapotrzebowania na usługi

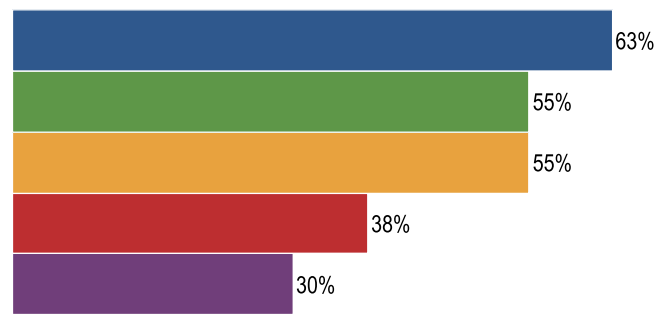

do $10 \mathrm{mln} \square 10-25 \mathrm{mln} \square 25-50 \mathrm{mln} \square 50-100 \mathrm{mln} \square$ powyżej $100 \mathrm{mln}$

Silny negatywny wpływ na działalność firm logistycznych (początek kwietnia 2020). Wielkość przychodów Zatory płatnicze

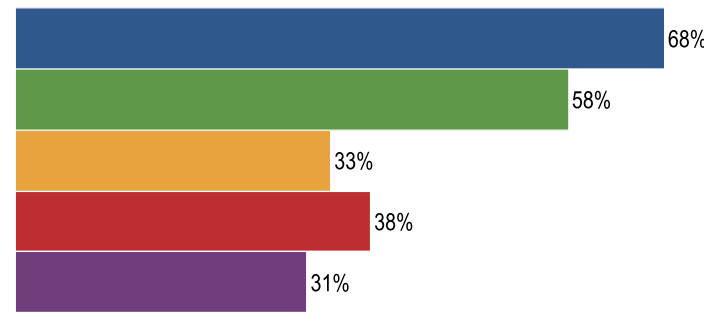

do $10 \mathrm{~m} / \mathrm{n} \square$ 10-25 mln $\square 25-50 \mathrm{~m} / \mathrm{n} \square$ 50-100 mln — powyżej $100 \mathrm{mln}$

Silny negatywny wpływ na działalność firm logistycznych (początek kwietnia 2020). Wielkość przychodów

Obciążenie zobowiązaniami finansowymi

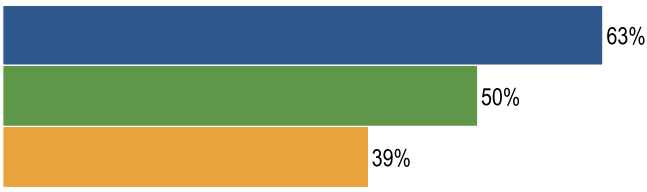

$0 \%$

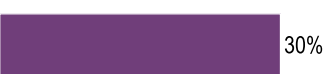

do $10 \mathrm{mln} \quad 10-25 \mathrm{mln} \quad 25-50 \mathrm{mln}$-50-100 mln — powyżej $100 \mathrm{mln}$
Silny negatywny wpływ na działalność firm logistycznych (początek kwietnia 2020). Wielkość przychodów Zerwanie tańcuchów dostaw międzynarodowych

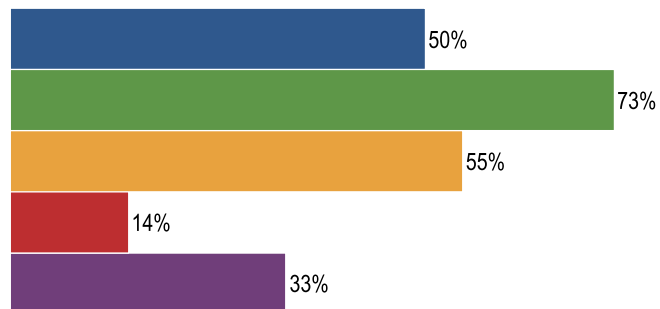

$\square$ do $10 \mathrm{mln} \square 10-25 \mathrm{mln} \square 25-50 \mathrm{mln} \square$ 50-100 mln $\square$ powyżej $100 \mathrm{mln}$

Silny negatywny wpływ na działalność firm logistycznych (początek kwietnia 2020). Wielkość przychodów

Obciążenie zobowiązaniami podatkowymi

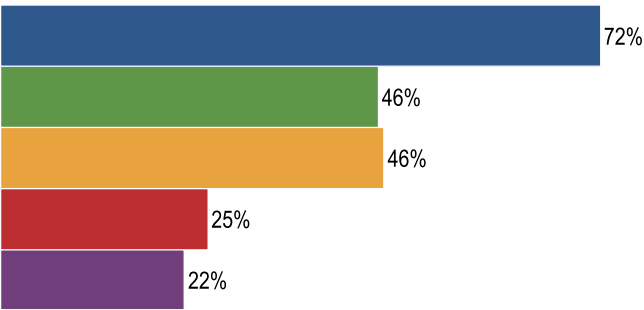

do $10 \mathrm{mln} \square$ 10-25 $\mathrm{mln} \square$ 25-50 $\mathrm{mln} \square 50-100 \mathrm{mln} \square$ powyżej $100 \mathrm{~m} / \mathrm{n}$

Blisko 2/3 (62\%) firm transportowych silnie odczuwa spadek popytu, dokładnie odwrotnie niz firmy wyspecjalizowane w logistyce kontraktowej czy usługach ekspresowych i kurierskich. Jeszcze lepszą sytuację deklarują firmy obsługujące handel elektroniczny. 
Zdecydowany WZROST aktywności zakupowej poszczególnych branż w dziedzinie zakupu usług logistycznych w marcu 2020

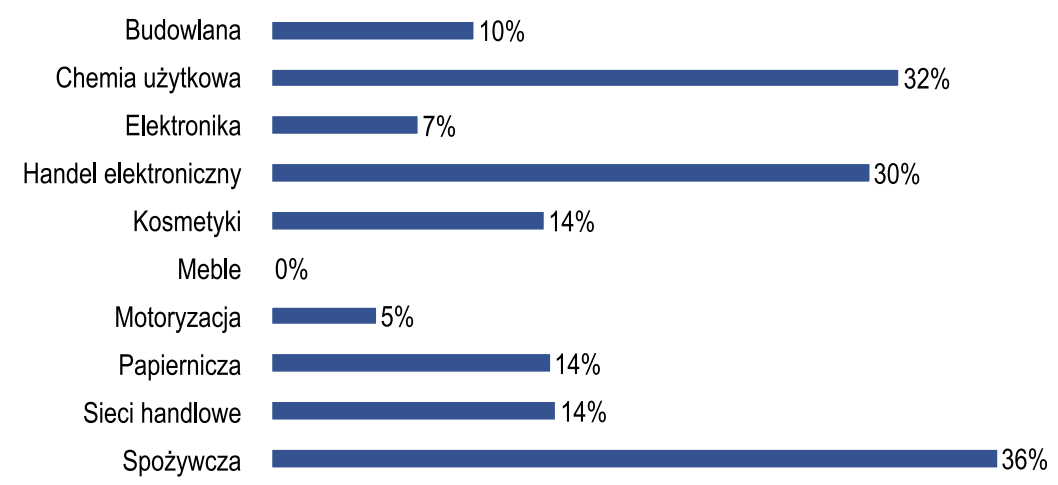

Zdecydowany SPADEK aktywności zakupowej poszczególnych branż w dziedzinie zakupu usług logistycznych w marcu 2020

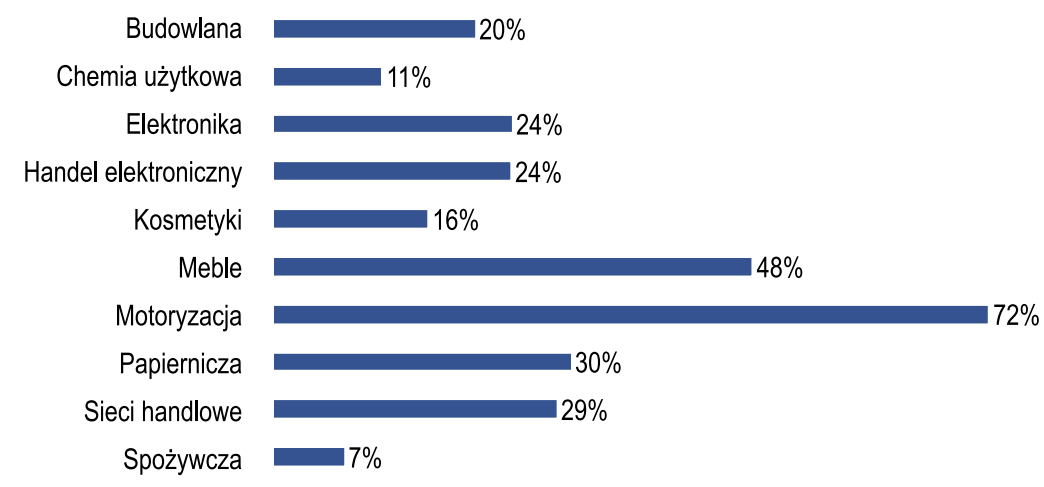

Aktywność zakupowa poszczególnych branż w dziedzinie zakupu usług logistycznych w marcu 2020

Skala ilościowa: 5 Zdecydowany wzrost, 4 Umiarkowany wzrost, 3 Bez zmian, 2 Umiarkowany spadek,1 Zdecydowany spadek

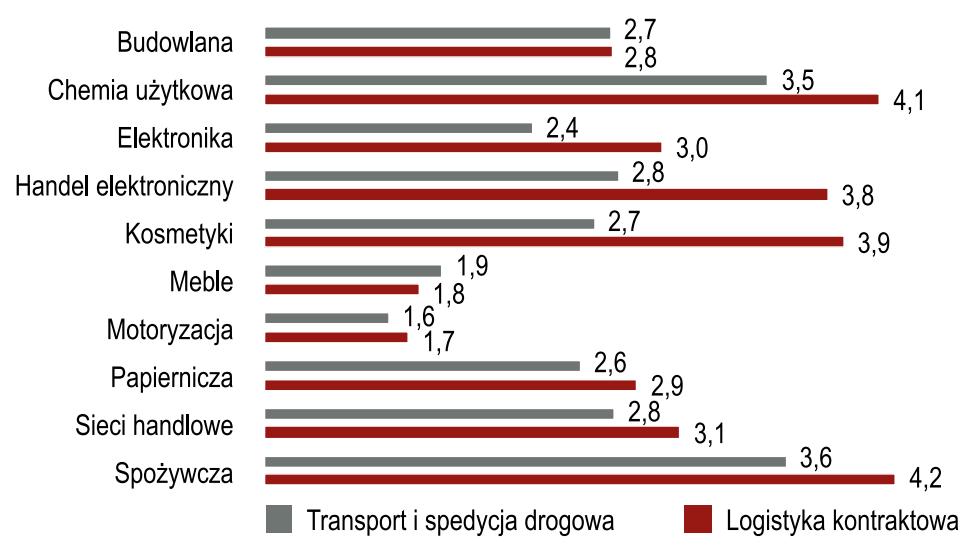




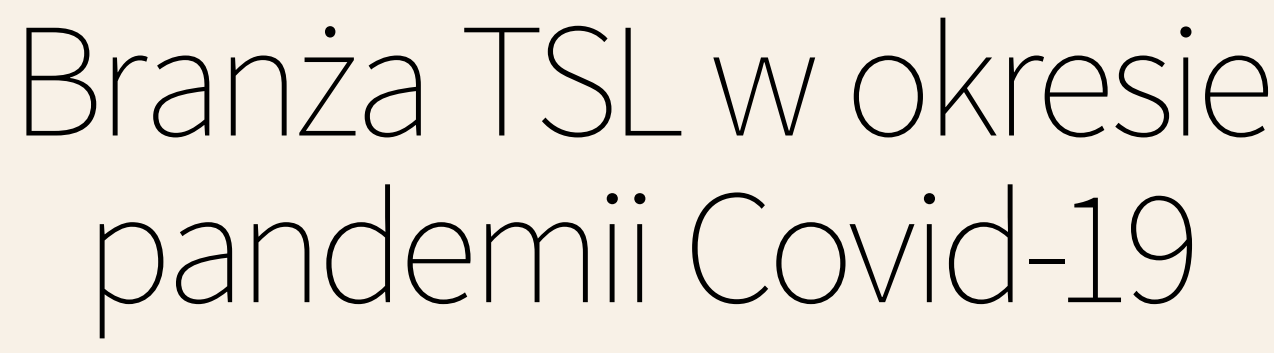

Udostępnione wyniki badań przeprowadzonych w pierwszym tygodniu kwietnia $2020 \mathrm{r}$. przez DGC/Eurologistics wśród licznej grupy respondentów z branży TSL pozwalają na sformułowanie wstępnego opisu procesu dostosowawczego usługodawców wobec destrukcyjnych zmian w ich otoczeniu. Porównywanie zakłóceń, które wywołała pandemia

Covid-19, w funkcjonowaniu globalnego systemu społeczno-gospodarczego do sytuacji występującej podczas jakiegokolwiek kryzysu gospodarczego nie ma w ogóle uzasadnienia.

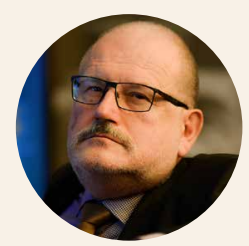

prof. dr hab. Wojciech Paprocki,

Instytut Infrastruktury, Transportu i Mobilności SGH

Blokada mobilności („zostań w domu”) mieszkańców prawie wszystkich krajów na świecie spowodowała, że prawie każdy inaczej musi się zachować w roli konsumenta oraz w roli uczestnika procesów gospodarowania. Zmienił się jednocześnie popyt oraz podaż produktów. Najtragiczniejsze jest to, że już po kilku tygodniach trwania pandemii część osób wcześniej aktywnych zawodowo straciła źródła przychodów. To zapowiada dalsze spadki popytu ogółem oraz drastyczne zmiany struktury popytu. Michael Kühne, 85-letni nestor branży TSL, w połowie kwietnia br. wyraził się dobitnie: „Wszyscy na tym stracimy i to wiele”.

Menedżerowie i etatowi pracownicy, a także tysiące osób pracujących „na samozatrudnieniu”, wykazują dwie podstawowe cechy: kompetencję i hart ducha. To powoduje, że branża TSL (nie tylko w Polsce) zapewnia właściwą obsługę społeczeństwa (zaopatrzenie, w tym dostawy kurierów) oraz gospodarki. Badania wskazują jednoznacznie: różnorodne negatywne zjawiska występują w każdej grupie usługodawców.

Jednorazowe badania, które przeprowadzono w początkowej fazie pandemii, stanowią punkt wyjścia dla analizy dynamiki i zakresu zmian, które będzie można rozpoznać w kolejnych sondażach. Dla osób, które rozpatrują różne scenariusze działania w kolejnych tygodniach i miesiącach, szczególnie duże znaczenie będą mieć dane o skali spadku popytu na usługi logistyczne i transportowe. Wówczas dowiemy się, jak długie jest pionowe ramię litery „„”. Następnie będziemy śledzić dane, aby zobaczyć, czy ta litera ewoluuje w kierunku litery „U”. Wypada nam wszystkim życzyć, aby nie było to „UuuuuuuU” tak długie jak wanna, w której można się wygodnie wyciągnąć.

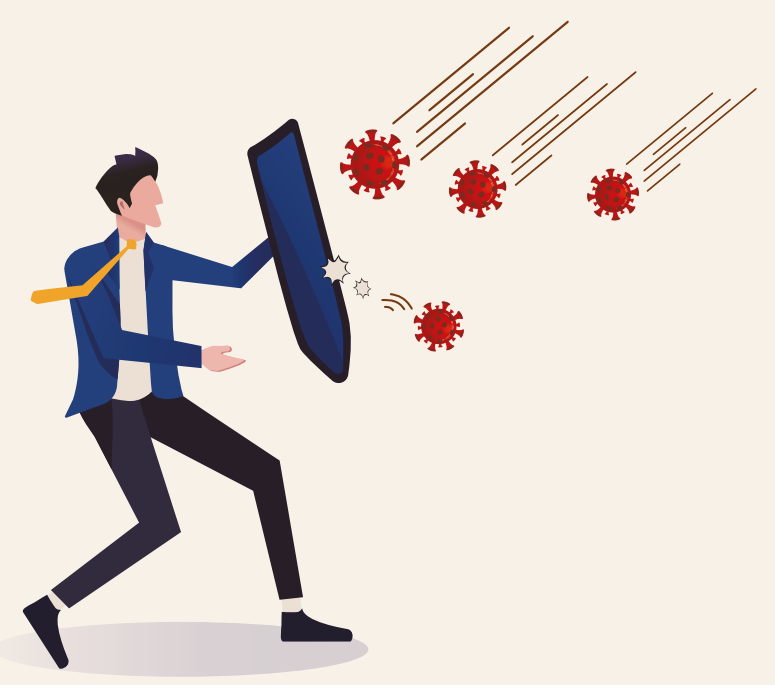




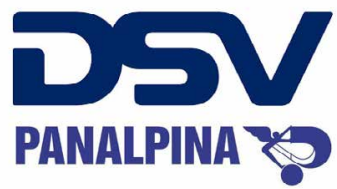

Choć jeszcze w lutym epidemia miała ograniczony wpływ na rynki logistyczne, dotycząc dostaw towarów w relacji z Chinami, to już w połowie marca „zainfekowała” globalny rynek logistyczny, destabilizując relacje pomiędzy podażą a popytem, oraz potencjał przewozowy. Prognozy wyników sprzedaży przedsiębiorstw przestały być aktualne. „Ze względu na zmianę perspektyw dla globalnych łańcuchów dostaw, oraz rynków transportu i logistyki, oczekujemy negatywnego wpływu na naszą działalność i wyniki finansowe w nadchodzących miesiącach. Biorąc pod uwagę zmieniającą się z dnia na dzień sytuację na wielu rynkach, obecnie nie jesteśmy w stanie dokładnie ocenić skali tego wpływu, dlatego wycofujemy nasze prognozy na 2020 r. do czasu wyjaśnienia zmian na rynku i oceny rzeczywistego wpływu finansowego na naszą działalność" - napisała w oświadczeniu centrala grupy DSV Panalpina.

\section{Filip Czerwiński, prezes zarządu polskiej spółki DSV Road:}

- Pandemia ma bezpośredni negatywny wpływ na ekonomię i działalność gospodarczą - zakłady produkcyjne są czasowo zamykane bądź ograniczają produkcję. Nie jest również pewne, jak sytuacja rynkowa będzie się kształtować po wygaśnięciu pandemii. Wielu ekonomistów prognozuje, że dojście do pełnej aktywności gospodarczej może zająć nie kilka, lecz kilkanaście miesięcy”. Pogarszające się realia gospodarcze mają wpływ na funkcjonowanie firm logistycznych i wymuszają konieczność odpowiedniego przygotowania do trud- nej sytuacji rynkowej. W najtrudniejszym okresie najbliższych miesięcy także firmy logistyczne będą wymagały finansowania ze strony państwa, choć istnieje obawa, że program pomocowy będzie opóźniony, a jego działanie skierowane jedynie do firm notujących znaczący spadek obrotów, „po spełnieniu wymogów formalnych”. Na szczęście pracujemy w branży, której usługi są niezbędne do zapewnienia ciągłości zaopatrzenia i produkcji.

Priorytetem jest dbałość o zdrowie wszystkich pracowników i przestrzeganie wytycznych administra- cyjnych i przyjętych wewnętrznie dodatkowych środków bezpieczeństwa. Większość naszych pracowników wykonuje swoje zadania zdalnie pracując z domu, a miejsca pracy dla osób, które nie mają takiej możliwości zostały odpowiednio przygotowane i zabezpieczone. Poszczególne strefy biurowe są wydzielone tak, że pracownicy poszczególnych komórek i działów nie mają ze sobą styczności. Kontakt pracowników magazynowych, biurowych i kierowców jest ograniczony do minimum.

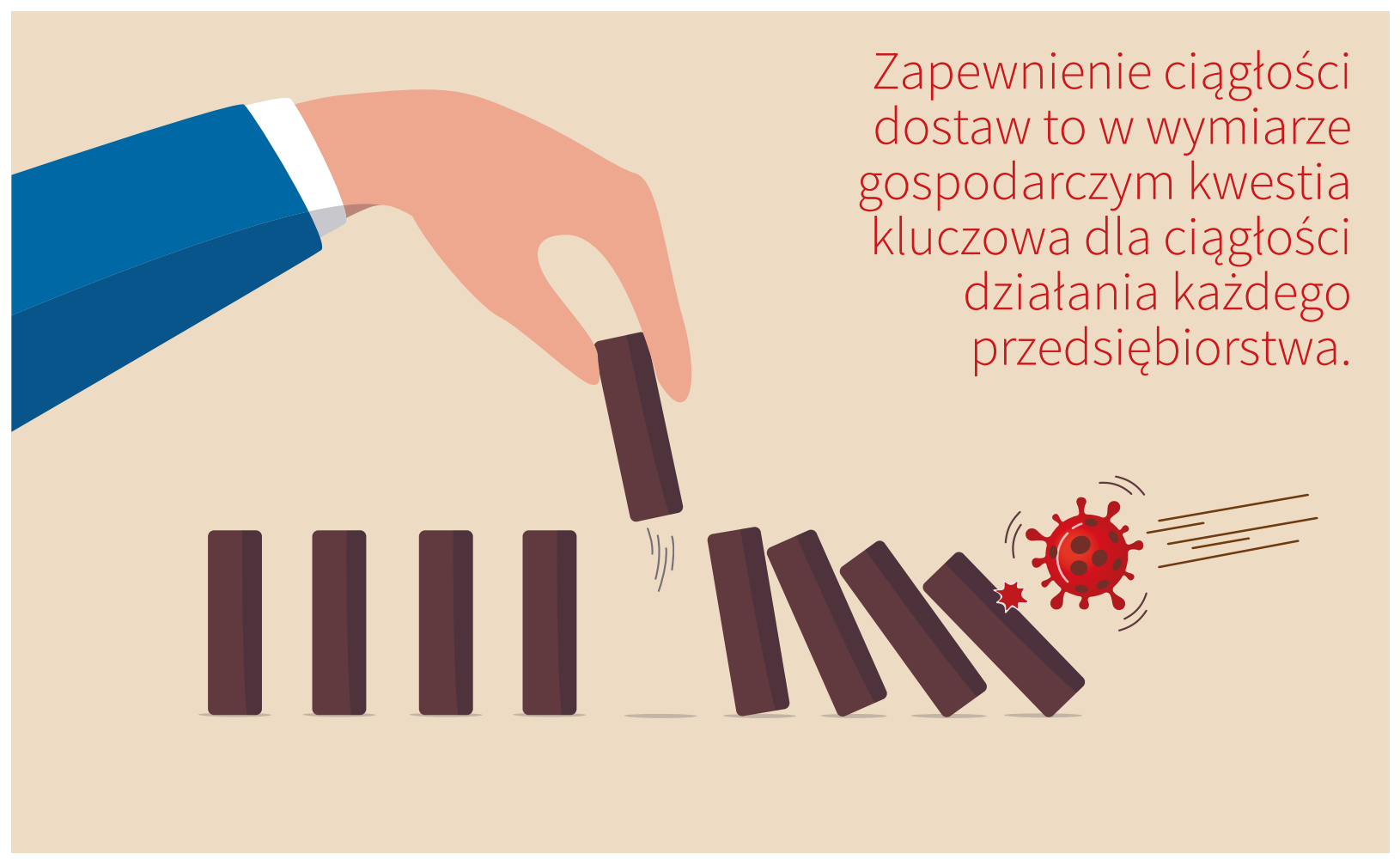




\section{your partner in logistics}

O ile inne dziedziny życia gospodarczego mogą podlegać w dobie pandemii administracyjnym ograniczeniom, to branża logistyczna jest od nich zasadniczo wolna, gdyż w żadnym razie nie można dopuścić do załamania dostaw towarów. Zapewnienie ciągłości dostaw to w wymiarze gospodarczym kwestia kluczowa dla ciągłości działania każdego przedsiębiorstwa.

Olga Żerkowska, grupowy menedżer ds. obsługi klienta, Raben:

- Kluczową kwestią jest zapewnienie ciągłości działania każdej firmy na rynku. Jesteśmy gotowi do obsługi przesyłek i wychodzimy naprzeciw aktualnym potrzebom naszych klientów. Wszyscy, współpracujący z nami kierowcy, nasi magazynierzy, dyspozytorzy, dział obsługi klienta i cały nasz zespół dokładamy największych starań, aby logistyka nie zatrzymała się oraz by wesprzeć naszych klientów, pomóc magazynować i dostarczać potrzebne produkty. W ostatnich tygodniach nastąpit istotny wzrost zapotrzebowania na artykuły pierwszej potrzeby, czyli żywność i chemię gospodarczą, równocześnie zauważalny jest spadek ilości towarów pozostałych branż, w których nastąpiło spowolnienie. Dostosowaliśmy się elastycznie do tej sytuacji i towary na terenie naszego kraju są dostarczane planowo. W transporcie międzynarodowym mierzymy się z ograniczeniami wprowadzonymi przez poszczególne kraje i poszukujemy optymalnych rozwiązań. Naszym priorytetem jest zapewnienie dostępności produktów pierwszej potrzeby. Postępujemy zgodnie z regulacjami wprowadzanymi przez odpowiednie służby krajowe oraz zaleceniami WHO, a nasz sztab kryzysowy przez cały czas monitoruje sytuację. Dokładamy wszelkich starań, aby dostawy odbywały się w sposób jak najbardziej bezpieczny. Wprowadziliśmy szereg środków ostrożności, m. in. pomiar temperatury ciała i płyny dezynfekujące na wejściu/wjeździe do naszych obiektów, rękawice ochronne w punktach przyjęcia dokumentów, przerwy pomiędzy zmianami w magazynach i dodatkowe dezynfekcje pomieszczeń socjalnych.

\section{Hysepta Anti-Virus +}

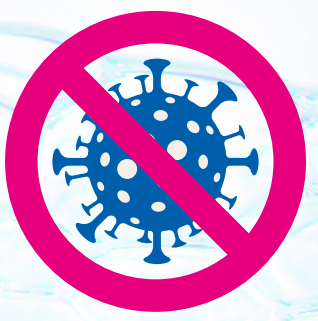

\section{Rekomendowany przez WHO Atestowany płyn do dezynfekcji rąk i urządzeń}
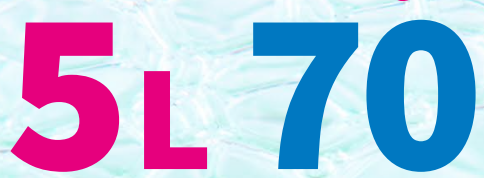

\section{HYSEPTA ANTI-VIRUS +}

PEYN DO CHIRURGICZNEJ DEZYNFEKCJI RAK,

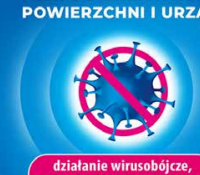

4) 企

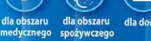

(3) (70\%) (Gत्)

\section{Dziatanie wirusobójcze, bakteriobójcze i grzybobójcze}

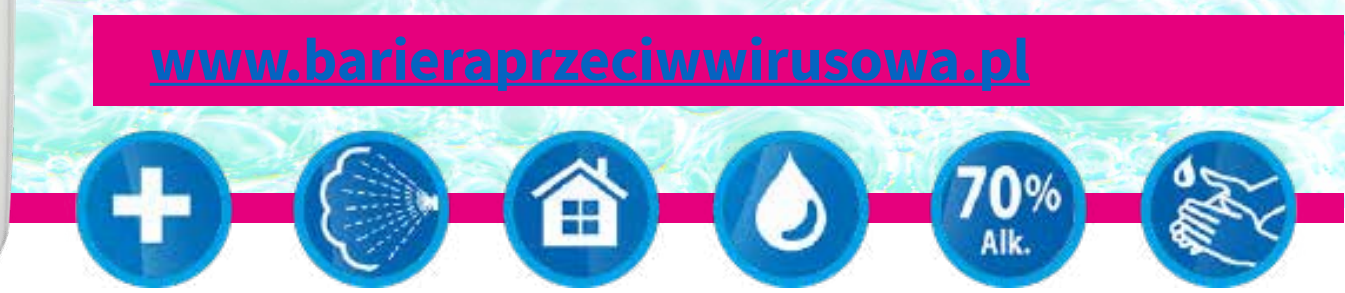




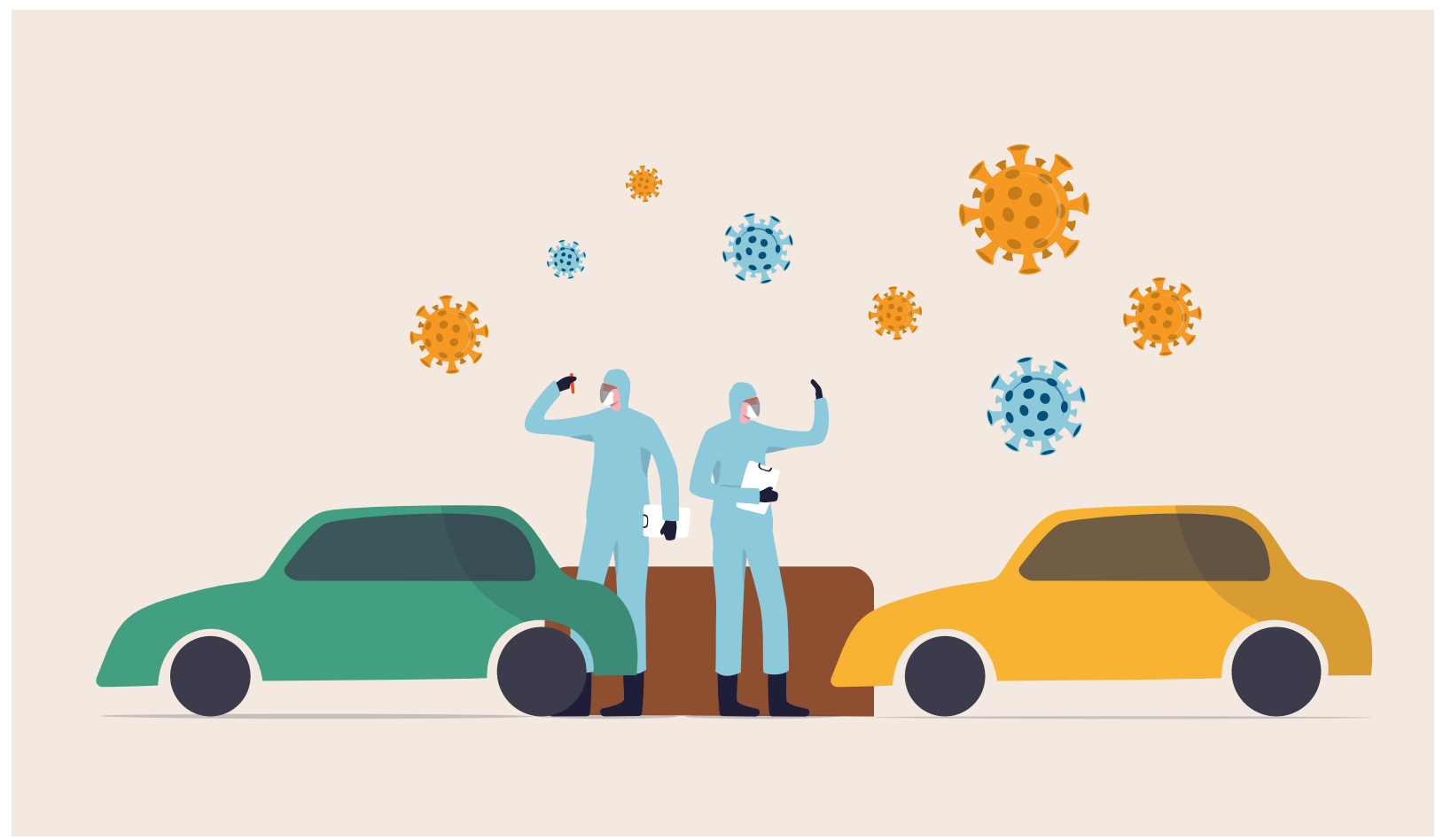

\section{Branża motoryzacyjna}

Branża motoryzacyjna silniej niż inne odczuła już pierwszy atak wirusa SARS-Cov-2 w Chinach, gdyż ze względu na wstrzymanie produkcji i wywozu ładunków z tego kraju groziło niebezpieczeństwo wyczerpania zapasów w fabrykach na całym świecie do końca marca, jak szacuje McKinsey. Obecnie ryzyko związane z organizacją dostaw just in time lub utrzymywania niskiego poziomu zapasów zdecydowanie osłabło ze względu na zamykanie fabryk w USA i UE z powodu rozprzestrzeniania się wirusa także na tym obszarze. Przedsiębiorstwa produkcyjne gwałtownie obniżyły poziom zapasów z kilkutygodniowego na kilkudniowy, spadło też zapotrzebowanie na części zamienne z sektora usług. Przy spadającym popycie sprawność łańcuchów dostaw w najbliższych tygodniach może być utrzymana, a czas realizacji zamówień może się nawet poprawiać. Jednakże niestabilność gospodarcza i widmo recesji w wyniku rozprzestrzeniania się pandemii i ewentualnego jej nawrotu w najbliższych miesiącach mogą pogłębić ryzyko załamania systemu dostaw. Uniknięcie tego stanu będzie wymagało od uczestników rynku przemodelowania systemu dostaw, z większym niż miało to miejsce dotąd udziałem regionalnych dostawców podzespołów. Otwiera to wprawdzie w przyszłości szanse dla zlokalizowanych w naszym kraju producentów, lecz jednak obecnie branża motoryzacyjna pogrążona jest w głębokim kryzysie. Kładzie się to cieniem na branży logistycznej. Dotyczy to szczególnie tych firm, które są wyspecjalizowane w obsłudze dostaw dla motoryzacji. Firmy te prawie całkowicie utraciły dotychczasowe zamówienia, co więcej, jak można wnioskować z nieoficjalnych wypowiedzi, koncerny motoryzacyjne, ratując siebie, postanowiły wstrzymać płatności za usługi logistyczne wykonane w styczniu i lutym. Wywołuje to powstawanie zatorów płatniczych, ponieważ operatorzy logistyczni nie są w stanie uregulować należności swoim podwykonawcom. Oczywisty wniosek z tej sytuacji: rządowe wsparcie nie powinno zatem polegać wyłącznie na wypłacie gotówki dla samozatrudnionych i mikroprzedsiębiorstw, lecz także (a może przede wszystkim?) na poprawie płynności przedsiębiorstw (dużych i średnich), wymuszając na nich jednocześnie regulowanie zobowiązań. Walce z zarazą musi towarzyszyć uwolnienie przedsiębiorstw od obciążeń, gdyż załamanie gospodarki może mieć bardziej tragiczne skutki niż pandemia. Te działania muszą być szybkie i radykalne, obejmując już od maja pokrycie części pensji pracowników firm, które przestały działać. Pomoc państwa powinna być realna, nie powinno być np. mowy o przesunięciu obciążeń, lecz o ich umorzeniu za określony okres (nie miesiąc, ale trzy miesiące). Należy jednak zachować sceptycyzm, co do sprawczości władz. Z powodów ideologicznych nie ma co liczyć na uelastycznienie rynku pracy, skrócenie czasu wypowiedzeń, zmniejszenie odpraw itp., co dawałoby przedsiębiorcom pole manewru w walce o utrzymanie firm przy życiu. Jeśli tak się nie stanie, to nie można sobie wyobrazić, aby jakakolwiek firma była w stanie wypłacić kierowcy trzymiesięczną odprawę, gdy nie ma nawet pieniędzy na bieżące wynagrodzenie. 


\section{Frigo Logistics}

\section{Branża spożywcza}

Branża spożywcza z punktu widzenia obsługi logistycznej to w ciągu ostatnich tygodni sprzedażowy roller coaster, składający się głównie z „wysokich wzniesień, stromych spadków, gwałtownych zwrotów i inwersji". W obecnej sytuacji za tempo zmian popytu jednak nie odpowiadali jak zwykle specjaliści od marketingu, lecz trudne do przewidzenia masowe zachowania konsumentów. Duże różnice wzrostu i spadku zamówień w stosunku do oczekiwanych stanowią dla operatorów logistycznych olbrzymie wyzwanie. Wymagają nie tylko elastyczności, ale także błyskawicznego czasu reakcji na zmieniające się oczekiwania klientów. Weryfikacji podlegają możliwości operacyjne, firmy logistyczne na nowo też muszą oszacować, jakimi zasobami (pracownicy, tabor, powierzchnie magazynowe) muszą dysponować, aby sprostać zapotrzebowaniu. Mniejszym problemem było na ogół wprowadzenie nowych procedur mających na celu zachowanie jak najwyższego poziomu bezpieczeństwa podczas przyjęcia i wydania towaru w różnych obszarach działalności, choć kłopotliwe, przebiegło w firmach logistycznych sprawnie, sądząc po braku krytyki społecznej (za wyjątkiem przemieszczania się pracowników firmy Amazon).

Ewelina Gierak, menedżer ds. rozwoju biznesu, Frigo Logistics:

- Wysokość sprzedaży uwarunkowana była głównie obawą społeczeństwa przed wprowadzeniem drastycznych ograniczeń w dostępie do punktów sprzedaży oraz niepewności, co do dostępności produktów spożywczych w sklepach. Średnie dzienne ilości paletowych wydań wahały się od wzrostu na poziomie ponad 50\% w tygodniu 12 do spadku na poziomie 28\% w tygodniu przedświątecznym, który właściwie w każdej branży historycznie każdego roku odnotowuje wzrosty wolumenów.

Najważniejsze we wdrażaniu nowych procedur mających na celu zachowanie bezpieczeństwa podczas przyjęcia i wydania towaru są takie działania jak: kampania informacyjna wśród pracowników i kierowców promująca zachowania ograniczające rozprzestrzenianie się wirusa, stosowanie środków zabezpieczających, obowiązkowy pomiar temperatury, wprowadzenie zakazu wejścia kierowców do strefy magazynowej, bezpieczne przekazywanie ograniczonej do minimum dokumentacji papierowej, dezynfekcja pomieszczeń podczas przerw w trybie pracy na zmiany, utworzenie osobnych dróg komunikacyjnych dla pracowników kończących i zaczynających zmianę, podział pracowników na wydzielone grupy także podczas positków w stołówce.

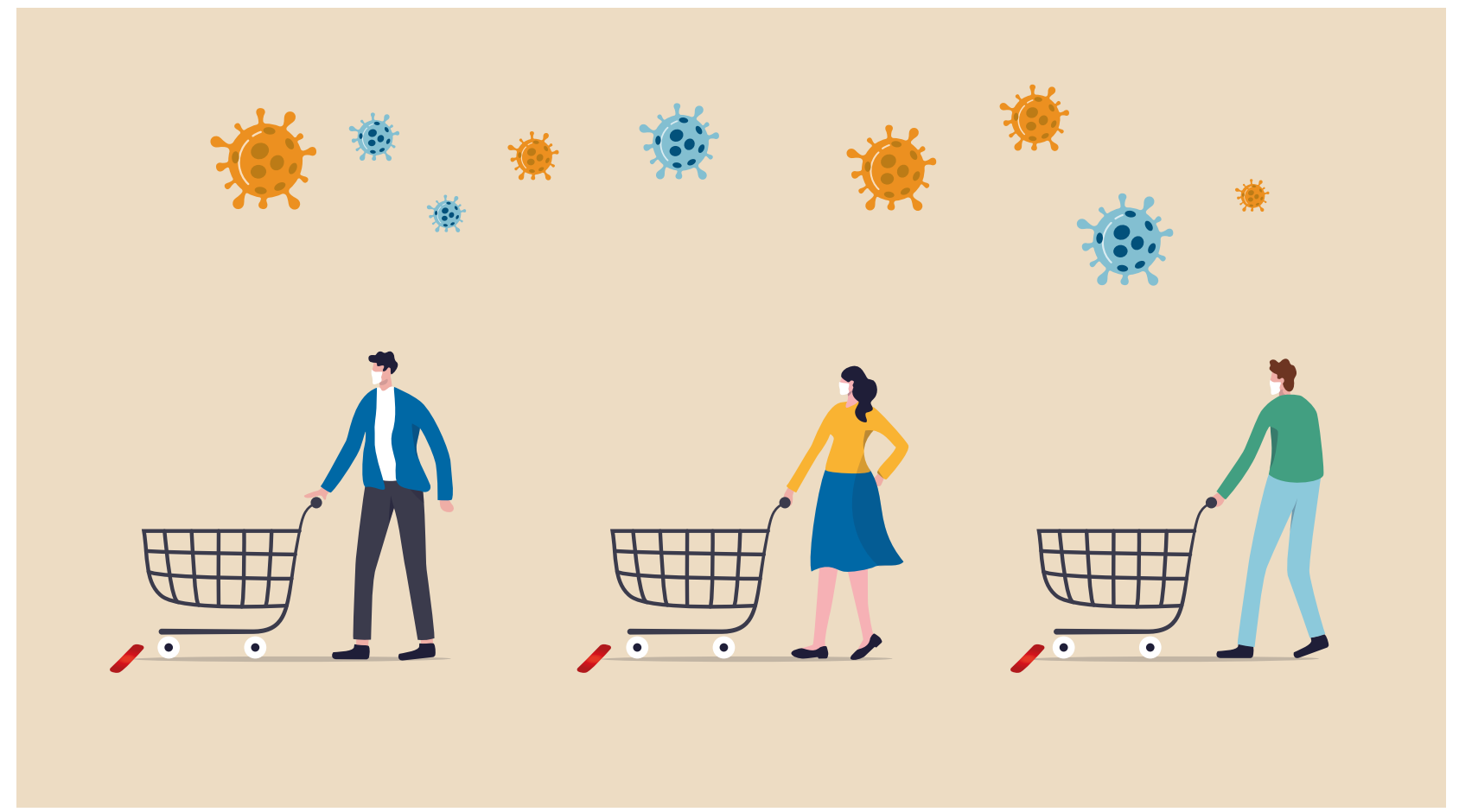

